\title{
Literasi Media Dalam Menangkal Radikalisme Pada Siswa
}

\author{
Fadhil Pahlevi Hidayat*, Faizal Hamzah Lubis \\ Program Studi Ilmu Komunikasi, Universitas Muhammadiyah Sumatera Utara, Medan, \\ Indonesia \\ *e-mail: fadhilpahlevi@umsu.ac.id
}

\begin{abstract}
.
Currently, smartphones are almost owned by the whole community, starting with children, adolescents, and the elderly. However, the use of smartphones, of course, cannot be separated from the positive and negative impacts on users, especially for students, one of which is about radicalism. Schools in Indonesia in recent years have become targets of radicalism. Thus, it is hoped that the understanding or critical thinking of students can counteract or be a starting point to turn off issues related to radicalism among these students. This study uses a qualitative descriptive approach with data study techniques, as well as data analysis techniques that use data, data reduction, data presentation, and data collection. The results showed that the ability of media literacy in warding off radicalism was at the basic level because the knowledge, ability to analyze and think of Nur Azizi High School students were still limited, however, Nur Azizi High School students were able to carry out functions in operating internet media at various levels. so complex, able to use the internet as needed, and see how to find, obtain, and assess information that is needed but not for messages or information related to radicalism.
\end{abstract}

\section{Keywords : Media literacy, Radicalism, SMA}

\begin{abstract}
ABSTRAK
Saat ini smartphone hampir dimiliki oleh seluruh kalangan masyarakat, dimulai dari anak-anak, remaja, orang tua. Namun penggunaan smartphone tentu saja tidak lepas dari dampak positif maupun dampak negatif bagi penggunanya, terutama bagi pelajar salah satunya tentang radikalisme. Sekolah- Sekolah di Indonesia pada beberapa tahun belakangan ini menjadi sasaran radikalisme. Dengan demikian, diharapkan adanya pemahaman atau pemikiran kritis bagi siswa-siswi sehingga dapat menangkal atau jadi titik awal untuk mematikan isu-isu terkait radikalisme di kalangan pelajar tersebut. Penelitian ini menggunakan pendekatan deskriptif kualitatif dengan teknik pengumpulan data wawancara serta teknik analisa data menggunakan pengumpulan data, reduksi data, penyajian data, dan penarikan kesimpulan. Hasil penelitian menunjukkan bahwa Kemampuan literasi media dalam menangkal radikalisme berada pada level basic dikarenakan pengetahuan, kemampuan menganalisis dan berpikir siswa-sisiwi SMA Nur Azizi masih terbatas, Namun siswa- siswi SMA Nur Azizi sudah mampu menjalankan fungsi-fungsidalam mengoperasikan media internet dengan berbagai tingkat yang begitu kompleks, mampu menggunakan internet sesuai kebutuhan, serta mengetahui cara untuk mencari, memperoleh dan menilai sebuah informasi yang dibutuhkan namun belum untuk pesan atau informasi yang berkaitan dengan radikalisme.
\end{abstract}

Kata kunci : Literasi Media, Radikalisme, SMA.

\section{Pendahuluan}

Berdasarkan Survei Badan Litbang

SDM Kominfo (Kominfo, 2017)

menunjukkan bahwa $66,3 \%$ atau lebih dari

setengah masyarakat Indonesia sudah

memiliki dan menggunakan telepon pintar atau smartphone dan berdasarkan pulau, Sumatera menjadi nomor dua terbesar dalam memiliki dan menggunakan smartphone yakni sekitar $84,14 \%$.

Penggunaan smartphone pada pelajar akan berdampak positif, seperti kemudahan 
dalam berdiskusi dan berkomunikasi, dapat mencari dan menemukan informasi secara cepat, serta meningkatkan wawasan pelajar. Tetapi, kemudahan dalam mencari informasi tersebut membuat berbagai informasi dengan mudah diterima pelajar terutama terkait isu radikalisme.

Menurut (Sudjito, 2018) Persoalan besar tengah dihadapi negeri ini, bukan hanya terletak pada pesoalan politik dan ekonomi saja, akan tetapi juga telah memasuki konteks sosial dan budaya. Sadar atau tidak sadar, kita telah disusupi dengan isu-isu radikal dengan tujuan agar masyarakat Indonesia menjadi terpecah belah. Hal ini sangat berkaitan ketika kita hubungkan dengan pesan yang disampaikan oleh sang proklamator, yakni Soekarno yang pada saat itu menyampaikan pidato kenegaraannya pada tahun 1956, dengan mengatakan bahwa "suatu bangsa tidak akan bisa berdiri tanpa suatu keyakinan (nation without faith can't stand). "Maka dari itu, sangatlah jelas bahwa setiap gerakangerakan radikal dan sikap intoleransi yang muncul di negeri ini bukanlah merupakan karakter dari bangsa Indonesia.

Menurut Muthohirin, gerakan-gerakan radikalisme semakin banyak muncul keruang-ruang publik di Indonesia. Berbagai aksi-aksi yang bersifat terorisme semakin hadir begitu pesat, dari aksi terorisme yang berskala kecil hingga aksi yang berskla besar. Aksi-aksi terorisme tersebut juga terjadi secara berulang-ulang dihadapan public. E-ISSN: 2580-6955
Berbagai langkah pemberantasan dan pencegahan dilakukan oleh pemerintah terhadap kelompo-kelompok teroris yang terus bermunculan. Fenomena-fenomena seperti ini menjadi tanda-tanda kemunculan gerakan radikalisme (Muthohirin, 2015).

Faktor yang paling efektif dan memungkinkan munculnya dengan mudah isu atau aksi radikalisme adalah faktor latar belakang sosial dan budaya yang beraneka ragam, dan juga faktor agama. Radikal dapat ditafsirkan sebagai suatu sikap ekstrim tentang sebuah keyakinan dan tidak memberikan sikap toleransi bagi kelompok yang bertentangan dengan mereka. Indonesia yang merupakan bangsa dengan berbagai kemajemukannya menjadi wadah yang sangat potensial untuk menghadirkan aksi-aksi radikal. Aksi-aksi radikal tersebut dapat hadir dengan latar belakang agama, suku, dan golongan tertentu.

Menurut (Nuruzzaman, 2019) kelompok teroris mendapatkan keuntungan tersendiri dengan hadirnya dunia digital. Sebagaimana yang dikatakan oleh Manuel Castells dalam pengamatannya melalui kacamata sosiologi komunikasi menyebutkan bahwa terorisme dan media mempunyai suatu keterikatan. Hal ini dapat dilihat dari tujuan terorisme tersebut, yaitu meneror dan politik media. Aksi-aksi terorisme diarahkan untuk mencapai kesadaran publik sedangkan pemberitaan dari media untuk membentuk opini publik. Segala bentuk terorisme Publisher : UMSU Press 
berorientasi pada media guna menghadirkan tanggapan dan liputan yang spektakuler.

Pada umumnya, penggunaan internet oleh kelompok-kelompok teroris membagi dua jenis kelompok teroris, yakni cyberterrorism dan propaganda online. Cyberterrorism merupakan tindakan dalam menggunakan internet untuk memusnahkan, menyakiti, menyerang, seseorang atau properti dengan mengubah, merusak, menyebarkan virus pada situs-situs, serta menyisipkan pesan-pesan radikal situs orang lain. Sedangkan propaganda online merupakan kegiatan yang dilakukan untuk kepentingan propaganda, radikalisasi, dan rekruitmen oleh sekelompok orang dan menjadikan kelompok tersebut sebagai kelompok teroris dengan menggunakan internet sebagai media perekrutan (Nuruzzaman, 2019).

Beberapa kasus terorisme pernah terjadi, contohnya pada kasus bom bunuh diri yang terjadi di Medan yang membuat masyarakat merasa was-was jika berdekatan dengan orang asing. Pasalnya, pelaku bom bunuh diri biasanya merupakan seseorang yang tidak diketahui secara jelas identitasnya. Meskipun begitu, masyarakat diminta untuk tidak berlebihan dalam mencurigai orang asing karena justru akan merusak kehidupan bermasyarakat (Ayu, 2019).

Saat ini paham-paham radikalisme dinilai masih mempunyai ancaman serius bagi keberlangsungan kehidupan berbangsa E-ISSN: 2580-6955 dan bernegara. Akademisi Komunikasi Fisip Unsyiah, Rahmat Saleh menyatakan, radikalisme menjadikan kaum muda sebagai sasaran untuk direkruitmen. Maka dari itu, kaum muda sangat penting untuk memiliki bekal pengetahuan dan pemahaman yang baik dan benar terutama tentang media serta konsumsi konten media (Warsito, 2019).

Sekolah-Sekolah di Indonesia pada beberapa tahun belakangan ini menjadi sasaran radikalisme. Menurut Al Ayyubi berdasarkan data yang didapatkan dari Lembaga Kajian Islam dan Perdamaian (LaKIP), data itu menyebutkan sekolah memang rawan dipengaruhi dengan radikalisme, dimana seharusnya sekolah menjadi tempat menuntut ilmu bagi generasi muda, dengan persentase 48,9\%. Maka, dapat dikatakan bahwa tindakan radikal di sekolah didukung oleh para siswa (Al Ayyubi, 2019).

Selain itu, tahun 2017, telah dilakukan penelitian oleh (Mutohar, 2018) di Jawa Tengah terhadap 20 Sekolah Swasta Islam dan bekerja sama dengan akademisi dari Monash University dari Australia, Universitas Islam Negeri Walisongo dari Semarang, dan Universitas Gadjah Mada Yogyakarta yang juga didukung oleh Australia-Indonesia Centre.

Di Sumatera Utara, Sekolah SMA Swasta Nur Azizi Tanjung Morawa menjadi salah satu sekolah swasta terbesar dan banyak diminati oleh anak-anak terutama di Tanjung Publisher : UMSU Press 
Morawa. Walau Sekolah SMA Swasta Nur Azizi Tanjung Morawa bukan sekolah swasta islam, tetapi mayoritas murid-murid beragama islam. Kemudian, siswa-siswi SMA Swasta Nur Azizi Tanjung Morawa berdasarkan observasi, telah memiliki dan menggunakan smartphone dalam aktifitas nya sehari-hari.

Dengan demikian, diharapkan adanya pemahaman atau pemikiran kritis bagi siswasiswi sehingga dapat menangkal atau jadi titik awal untuk mematikan isu-isu terkait radikalisme di kalangan pelajar tersebut. Dan yang terpenting pelajar harus meningkatkan atau imunitas nya terhadap cara berpikir yang baik dan bijak serta sangat memerlukan akan literasi media terhadap terpaan informasiinformasi tersebut.

Literasi media dapat dikatakan sebagai keahlian atau kemampuan seseorang dalam mengakses, menganalisis, mengevaluasi, serta mengkomunikasikan isi atau konten dari media tersebut. Kemampuan literasi media sangat dibutuhkan oleh masyarakat saat ini, karena dengan melek media masyarakat dapat meningkatkan kemampuan analisis dan mendekontruksi pesan sehingga dapat membuat atau memilih isi pesan dari media (Hidayat \& Ginting, 2020).

Kata Literasi media terdiri atas dua suku kata, yakni literasi dan media. Literasi dapat diartikan sebagai melek media, yaitu kemampuan dalam membaca dan menulis. Sedangkan media diartikan sebagai sarana untuk memperantarai sesuatu baik dalam wujud benda, manusia, maupun peristiwa. Oleh karena itu, literasi media merupakan kemampuan seseorang untuk mencari, memahami, dan memanfaatkan sumbersumber dari berbagai media dalam berbagai bentuk (Kurniawati \& Baroroh, 2016).

Menurut (Novianti \& Fatonah, 2018) Secara sederhana Pemahaman literasi media merupakan kemampuan individu dalam menyaring atau memilih isi pesan yang diberikan oleh media. Setiap individu mampu memilih isi pesan yang dianggap baik dan isi pesan yang dianggap buruk. Fase literasi media ini, individu sudah semakin aktif, kritis serta cerdas menggunakan media. Bahkan individu ketika menerima pesan dari media, akan dianalisis terlebih dahulu sebelum dapat dipercaya atau tidak informasi tersebut. Dengan demikian, literasi media sangat penting agar menjadi edukasi dalam ber media. Kompetensi dalam memberikan kesadaran mengenai konten dan dampak yang ada pada media, serta menjadi kontrol bagi seseorang dalam menggunakan media disebut dengan literasi media. Seseorang ketika dapat mengatur dalam menggunakan media akan memilah-milah konten atau isi media yang ingin dicari atau didapatkan sesuai dengan kebutuhan. Maka dari itu, literasi media dapat dikatakan sebagai kemampuan dalam memahami, menganalisis dan mendekonstruksi isi pesan dari sebuah media (Hidayat, 2018). 
Saat ini, hal terpenting dalam membuat prestasi generasi muda meningkat dan meraih kesuksesan adalah dengan penguasaan literasi. Menanamkan pemahaman akan literasi harus dilakukan sejak dini atau kecil karena pemahaman literasi akan menjadi fondasi utama guna membentuk generasi yang cerdas dan berbudaya. Indonesia sedang mengalami permasalahan tentang tingkat pemahaman literasi yang begitu rendah. Berdasarkan survei pada tahun 2015 yang dilakukan oleh Programme for International Student Assessment (PISA) di negara Indonesia, menunjukkan bahwasanya dari 69 negara yang dievaluasi, negara Indonesia berada pada peringkat 62,61, dan 63 dalam bidang sains, membaca, dan matematika dari. Padahal budaya dalam literasi memiliki manfaat guna menciptakan generasi muda yang berperan dalam membangun kehidupan bangsa dan negara (Lamada, 2019).

Literasi dapat menjadi senjata yang penting dalam menghindari dan mengkritisi isu-isu yang mengadung radikalisme dalam sosial media. Dengan menerapkan literasi yang baik, maka akan menciptakan pelajar yang cerdas, kritis, jauh dari hal-hal berbau kekerasan atau memecah belah serta dapat memilah dan memilih informasi-informasi apa saja yang diterima. Maka dari itu, dari uraian diatas penelitian ini akan meneliti tentang Literasi Media dalam Menangkal Radikalisme Pada Siswa, dimana tempat penelitian ini adalah SMA Swasta Nur Azizi Tanjung Morawa.

\section{Metode Penelitian}

Pendekatan deskriptif kualitatif menjadi pilihan dalam penelitian ini.. Pendekatan ini dipilih agar dapat menjelaskan tentang kemampuan literasi media dalam menangkal radikalisme pada siswa-siswi di SMA Nur Azizi Tanjung Morawa. Seperti yang dikatakan oleh (Noor, 2014) yakni penelitian yang bersifat deskriptif adalah penelitian yang mendeskripsikan suatu kejadian, peristiwa, dan gejala dengan memusatkan perhatian pada masalah-masalah aktual yang sedang terjadi saat ini. Dengan penelitian deskriptif, penelitian ini akan mendeskripsikan peristiwa dan kejadian yang menjadi pusat perhatian tanpa memberikan perlakuan khusus pada peristiwa tersebut.

Penelitian ini menggunakan data primer dan data sekunder. Data primer merupakan data yang dikumpulkan berdasarkan wawancara dengan subjek penelitian sebagai berikut:

\section{Tabel 1:}

Subjek Penelitian

\begin{tabular}{ccc}
\hline Nama & Umur & $\begin{array}{c}\text { Media yang } \\
\text { digunakan }\end{array}$ \\
\hline Aris Pranata & 17 Tahun & $\begin{array}{c}\text { Google/Internet, } \\
\text { Youtube, Fb }\end{array}$ \\
Aldila Fitri & 17 Tahun & Internet \\
Hendrawan & 17 Tahun & Internet
\end{tabular}




\begin{tabular}{lcc}
\hline \multicolumn{1}{c}{ Nama } & Umur & $\begin{array}{c}\text { Media yang } \\
\text { digunakan }\end{array}$ \\
\hline $\begin{array}{l}\text { Widya } \\
\text { Almareza }\end{array}$ & 17 Tahun & Internet \\
$\begin{array}{l}\text { Shakila Kelana } \\
\text { Putri }\end{array}$ & 17 Tahun & Internet \\
M. Faisal Hrp & 16 Tahun & Hp atau Internet \\
\hline
\end{tabular}

Sedangkan data sekunder merupakan data yang dikumpulkan dari berbagai bukubuku, jurnal, laporan penelitian dan berita online.

Analisis data yang digunakan dalam penelitian kualitatif menggunakan cara yang sistematis dengan menguraikan apa yang sedang diteliti. Selain itu, analisis data kualitatif juga mengatur hasil wawancara agar dapat dipahami dan bisa disajikan dengan orang lain (Kasiran, 2010).

Sedangkan Miles dan Hubermen dalam (Machfoedz, 2011) menyebutkan petunjuk secara garis besar mengenai langkah-langkah menganalisis data penelitian kualitatif, yakni dengan cara mengumpulkan data, mereduksi data, menyajikan data dan menarik kesimpulan.

\section{Hasil Penelitian dan Pembahasan}

Secara karakteristik, personal competence adalah kemampuan individu untuk menganalisis konten media serta menggunakannya. Personal competence memiliki dua indikator di dalamnya yakni Technical Skills dan Critical Understanding.
Technical skills merupakan keahlian individu yang mampu memahami dan mengoperasikan media yang digunakannya. Sedangkan Critical Understanding adalah keahlian individu dalam memahami, menganalisis dan mengevaluasi isi/konten pada media.

Dalam indikator technical skills seluruh informan pada penelitian ini mengungkapkan bahwa mereka cukup mampu dalam menggunakan dan memahami bagian-bagian dalam media yang digunakan. Bagi mereka, walau tidak sepenuhnya ahli dalam menggunakan dan paham mengenai fitur-fitur media tersebut, tetapi mereka sudah terbiasa menggunakannya, terutama media tersebut sudah menjadi bagian dari kegiatan rutinitas sehari-hari sehingga mereka dapat menggunakan dan memahami fitur-fitur pada media yang digunakan.

Peneliti mengategorikan media apa saja yang digunakan oleh informan untuk mencari informasi. Dengan menanyakan hal tersebut peneliti dapat mengetahui bahwa informan (siswa-siswi) cenderung menggunakan media yang sama.

Tercatat semua siswa-siswi menggunakan media internet dalam mencari informasi untuk kebutuhan sehari-hari. Berbagai alasan diungkap oleh para siswasiswi ketika mereka memilih internet sebagai media dalam mencari informasi. Selain mudah memahami dan lebih mudah dijangkau, siswa-siswi juga mengatakan bahwa dengan menggunakan internet untuk Publisher : UMSU Press 
mencari informasi tidak banyak membuangbuang waktu tidak ribet atau sulit dalam mencari informasi dan lebih mudah cara menggunakannya.

Ketika menggunakan media-media tersebut para siswa-siswi memiliki durasi yang beragam dalam mencari informasi. Durasi menggunakan media tersebut tergantung sesuai kebutuhan informasi yang dibutuhkan oleh para siswa-siswi. Secara keseluruhan, para siswa tidak akan berlamalama dalam mencari informasi, ketika sudah mendapatkan informasi yang dibutuhkan atau diperlukan, maka para siswa-siswi akan mengakhiri pencarian informasi tersebut.

Dalam penguasaan fitur-fitur media yang ada dalam menggunakan informasi tersebut, secara keseluruhan semua siswadan siswi sudah cukup menguasai dan memahami fitur-fitur yang digunakan. Hal ini dikarenakan ada beberapa fitur-fitur yang ada di internet para siswa-siswi tidak terlalu memahami karena bagi mereka tidak perlu semua harus dipahami, namun para siswasiswi sudah menguasai dan memahami fiturfitur yang ada untuk mencari informasi.

Ketika menggunakan media-media tersebut para siswa-siswi memiliki durasi yang beragam dalam mencari informasi. Durasi menggunakan media tersebut tergantung sesuai kebutuhan informasi yang dibutuhkan oleh para siswa-siswi. Secara keseluruhan, para siswa tidak akan berlamalama dalam mencari informasi, ketika sudah E-ISSN: 2580-6955 mendapatkan informasi yang dibutuhkan atau diperlukan, maka para siswa-siswi akan mengakhiri pencarian informasi tersebut.

Dalam penguasaan fitur-fitur media yang ada dalam menggunakan informasi tersebut, secara keseluruhan semua siswadan siswi sudah cukup menguasai dan memahami fitur-fitur yang digunakan. Hal ini dikarenakan ada beberapa fitur-fitur yang ada di internet para siswa-siswi tidak terlalu memahami karena bagi mereka tidak perlu semua harus dipahami, namun para siswasiswi sudah menguasai dan memahami fiturfitur yang ada untuk mencari informasi.

Pada indikator critical understanding, dimana untuk memahami, menganalisis dan mengevaluasi konten atau isi pesan dalam media, para siswa-siswi dikategorikan mampu mengevaluasi nya. Sebab, informasi yang diperoleh oleh siswa-siswi yang dicari atau mereka dapat, mudah dipahami jika dibaca dengan teliti secara keseluruhan dan hanya cukup sekali membaca sudah bisa dipahami. Selain itu, untuk memahami informasi dengan cepat biasanya juga didukung dengan bahasa yang digunakan dalam informasi tersebut. Maka dari itu, ketika mereka mencari informasi, para siswasiswi akan mencari informasi dengan bahasa yang mudah untuk dipahami.

Selain memahami informasi, para siswa-siswi juga melakukan pencarian mengenai sumber informasi yang mereka cari atau dapatkan. Selain mengetahui dengan 
pasti siapa sumber yang memberikan informasi, siswa dan siswi juga memeriksa kembali kebenaran dari informasi tersebut. Dengan demikian, siswa dan siswi akan mengurangi kemungkinan mendapatkan informasi yang salah (hoax) mengingat pada saat ini, informasi hoax sangat banyak beredar di masyarakat.

Selanjutnya, siswa-siswi memiliki cara tersendiri dalam menganalisis bagaimana suatu informasi tersebut benar atau salah. Para siswa-siswi akan melihat dan membaca secara baik informasi tersebut, bahkan menurut mereka berita atau informasi hoax dapat dibedakan dari gaya bahasa dan kalimat yang ada pada informasi tersebut dan pada umumnya, berita atau informasi hoax tidak dilengkapi oleh tanggal dan hari yang jelas.

Berkaitan dengan indikator critical understanding peneliti juga menanyakan informasi seputar radikalisme yang mereka tahu, dapat atau mereka cari dari mediamedia informasi yang mereka gunakan. Secara keseluruhan, para siswa-siswi tersebut mengetahui apa yang disebut dengan radikalisme.

Selanjutnya, siswa-siswi memiliki pemahaman atau pengertian sendiri tentang apa yang dimaksud dari radikalisme. Siswasiswi menyebutkan bahwa Radikalisme merupakan perilaku kekerasan, ingin mengubah ideologi dan sistem sosial dengan cara-cara kekerasan dan tetoris.
Namun, siswa-siswi tidak terlalu tertarik mengenai informasi yang berkaitan dengan radikalisme tersebut. Hampir seluruh siswa-siswi hanya mencari informasi mengenai radikalisme hanya sebatas keperluan saja. Bahkan, seorang siswa hanya cuek ketika mendapatkan informasi radikalisme, karena tidak begitu tertarik. Namun, ada juga yang harus mencari tahu informasi selanjutnya tentang radikalisme, karena informasi ini berkaitan dengan kekerasan jadi tidak bisa diterima begitu saja. Siswa-siswi secara keseluruhan mengkritisi informasi yang mereka dapat atau terima yang berkaitan dengan radikalisme. Bagi mereka, hal ini perlu dilakukan karena, informasi radikalisme yang ada unsur kekerasan di dalamnya harus dicari tahu kebenaran atau latar belakang peristiwa dari informasi serta bagaimana dampaknya. Selain itu juga para siswa-siswi mengkritisi nya dengan cara menanyakan informasiinformasi tersebut dengan orang tua mereka sehingga mereka tidak salah dalam memahami informasi radikalisme tersebut.

Social competence ini memiliki satu indikator yakni communicative abilities. Communicative abilities merupakan seseorang yang memiliki kemampuan untuk menggunakan, berpartisipasi dan berkomunikasi dalam media. Communicative abilities ini meliputi seseorang yang memiliki kemampuan melalui media dengan berpartisipasi dan menciptakan hubungan 
sosial pada lingkungan masyarakat dunia maya. Selain itu, communicative abilities juga mencakup kemampuan seseorang untuk membuat dan menciptakan konten pada media tersebut.

Berdasarkan hasil wawancara, dari para siswa-siswi mengenai communicative abilities, yang berkaitan dengan cara menciptakan konten dalam media secara keseluruhan siswa-siswi memberikan pernyataan yang sama. Menyusun konsep informasi yang ingin dibagikan, mencari sumber-sumber terpercaya untuk informasi tersebut, dan mencatat poin-poin penting dalam informasi menjadi cara siswa-siswi untuk menciptakan konten dalam menggunakan media.

Kemudian, siswa-siswi juga memiliki caranya tersendiri dalam membagikan suatu informasi dengan baik dan benar. Cara yang siswa-siswi lakukan tersebut seperti melakukan pemeriksaan kembali sumber informasi tersebut, menanyakan kepada orang tua jika tidak yakin informasi itu benar, setelah itu dibuat dengan bahasa atau kalimat yang mudah dipahami oleh teman- teman mereka.

Pada aspek partisipasi dan membangun jaringan (hubungan) sosial melalui media para siswa-siswi termasuk aktif, karena siswa-siswi dalam sehari- harinya menggunakan media-media tersebut tidak hanya untuk mencari informasi, tapi juga berkomunikasi seperti dengan keluarga, E-ISSN: 2580-6955 saudara, teman-teman, bahkan orang yang jarang ketemu atau dengan orang yang jauh sekalipun.

ketika mereka mendapatkan atau mencari informasi yang berkaitan dengan radikalisme, siswa-siswi SMA Nur Azizi berada pada level basic. Siswa-siswi Nur Azizi masih sangat sedikit mengenal dan mengetahui tentang radikalisme, hany sebatas mengetahui secara umum saja. Akan tetapi, informasi yang berkaitan dengan radikalisme tidak mereka terima begitu saja, mereka akan menanyakan terlebih dahulu jika mereka tidak ketahui, karena siswa- siswi tidak ingin mendapatkan informasi yang salah (hoax) tentang radikalisme tersebut.

Siswa-siswi Nur Azizi juga tidak tertarik mencari lebih dalam mengenai informasi radikalisme, karena bagi mereka radikalisme bukan merupakan informasi yang menarik untuk dibaca, bagi mereka radikalisme adalah informasi mengenai kekerasan, teroris, dan mengubah ideologi dengan paksa sehingga mereka sudah merasa cukup jika sudah mengetahui tentang radikalisme tersebut, terlebih lagi para siswasiswi SMA Nur Azizi tidak terlalu menyukai informasi yang berkaitan dengan kekerasan.

Sedangkan untuk personal competence dan social competence untuk tiga indikator, yakni technical skill, critical understanding, dan communicative abilities menunjukkan bahwa media literasi pada siswa-siswi SMA Nur Azizi Tanjung Morawa pada level Publisher : UMSU Press 
medium. Siswa-siswi sudah fasih dalam menggunakan media, dan sudah banyak mengetahui tentang fitur-fitur apa saja dalam media tersebut. Hal ini dikarenakan mereka sudah terbiasa menggunakan media tersebut kehidupan mereka sehari-hari.

Siswa-siswi SMA Nur Azizi juga ketika menggunakan media terutama dalam mencari informasi hanya sesuai kebutuhan, tidak terlalu intens. Dan ketika mendapatkan informasi melalui media, siswa-siswi tidak terlalu sulit untuk memahami informasi karena mereka akan membaca dengan teliti informasi tersebut. Walau demikian, mereka juga akan mencari informasi dengan bahasa atau kalimat yang mudah dipahami.

\section{Penutup}

Kemampuan literasi media dalam menangkal radikalisme berada pada level basic dikarenakan pengetahuan, kemampuan menganalisis dan berpikir siswa-siswi SMA Nur Azizi masih terbatas. Sedangkan kemampuan literasi media pada personal competence dan social competence dengan tiga indikator, yakni technical skill, critical understanding, dan communicative abilities berada pada level medium dimana siswasiswi SMA Nur Azizi sudah mampu menjalankan fungsi-fungsi tersebut serta mengoperasikan media internet dengan berbagai tingkat yang begitu kompleks, mampu menggunakan internet sesuai kebutuhan, serta mengetahui cara untuk mencari, memperoleh dan menilai sebuah informasi yang dibutuhkan namun belum untuk pesan atau informasi yang berkaitan dengan radikalisme.

\section{Daftar Pustaka}

Al Ayyubi, S. (2019). Begini Cara Menangkal Radikalisme Di Sekolah. Bisnis.Com. https://kabar24.bisnis.com/read/20191 009/16/1156981/begini-caramenangkalradikalisme-di-sekolah

Ayu, L. A. (2019). Hadapi Radikalisme Seperti Bom Medan, Apa Yang Harus Kita Lakukan? Kompas.Com. https://www.kompas.com/tren/read/20 19/11/13/190000265/hadapiradikalismeseperti-bom-medan-apayang-harus-kita-lakukan-

Hidayat, F. P. (2018). Literasi Media Terhadap Penggunaan Media Sosial Instagram Pada Mahasiswa di Kota Medan. 1-5.

Hidayat, F. P., \& Ginting, R. (2020). Media Literacy of Communication Students in Using Facebook. ETTISAL : Journal of Communication, $5(1)$. https://doi.org/10.21111/ejoc.v5i1.394 7

Kasiran. (2010). Metodologi Penelitian Kualitatif-Kuantitatif. UINMalikiPress.

Kominfo. (2017). Survey Penggunaan TIK Serta Implikasinya Terhadap Sosial Budaya Masyarakat. Badan Penelitian Dan Pengembangan Sumber Daya Manusia, 1-30.

Kurniawati, J., \& Baroroh, S. (2016). Literasi media digital mahasiswa Universitas Muhammadiyah Bengkulu. Jurnal Komunikator, 8(2), 51-66. http://journal.umy.ac.id/index.php/jkm/ article/view/2069 
Lamada, M. et al. (2019). Analisis Kemampuan Literasi Siswa SMK Negeri di Kota Makassar. Mekom, 1(6).

Machfoedz, I. (2011). Metode Penelitian Kuantitatif dan Kualitatif. Fitramaya.

Muthohirin, N. (2015). Radikalisme Islam dan Pergerakannya di Media Sosial. Afkaruna, 11(2), 240-259. https://doi.org/10.18196/aiijis.2015.00 50.240-259

Mutohar, A. (2018). Radikalisme Di Sekolah Swasta Islam: Tiga Tipe Sekolah Yang Rentan. TheConversation.Com. http://theconversation.com/radikalisme -di-sekolah-swasta-islam-tiga-tipesekolahyang-rentan-96722

Noor, J. (2014). Metodologi Penelitian; Skripsi, Tesis, Disertasi dan Karya Ilmiah. Prenada Media Group.
Novianti, D., \& Fatonah, S. (2018). Literasi Media Digital di Lingkungan Ibu-Ibu Rumah Tangga di Yogyakarta. Jurnal Ilmu Komunikasi, 16(1), 1-14.

Nuruzzaman, M. (2019). Pengaruh Media Sosial (Medsos) Terhadap Perkembangan Paham Radikalisme Di Kota Cirebon. Syntax Literate, 53(9), 1689-1699.

https://doi.org/10.1017/CBO97811074 15324.004

Sudjito, S. (2018). Membudayakan NilaiNilai Pancasila Dan Upaya Menangkal Tumbuhnya Radikalisme Di Indonesia. WASKITA: Jurnal Pendidikan Nilai Dan Pembangunan Karakter, 2(1), 116.

https://doi.org/10.21776/ub.waskita.20 18.002.01.1

Warsito, B. (2019). Pentingnya Literasi Media Untuk Cegah Radikalisme. JawaPos.Com. 